\title{
Structure of the Prague Basin: The deformation diversity and its causes (the Czech Republic)
}

\author{
PAVEL RÖHLICH
}

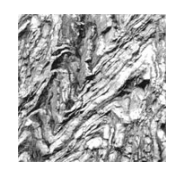

\begin{abstract}
The paper deals with the diversity of deformations, esp. faults, in the Ordovician to the Devonian deposits of the Prague Basin, their relations to the Proterozoic basement, and draws some conclusions about causes of this diversity. Attention is paid to the eastern, deeper downfolded part of the Basin (Prague Synclinorium). Some longitudinal faults (Liben Thrusts, Tetín Thrust) are confined to the basin filling and are apparently due to the release of stresses generated during folding. Most of faults, however, are rooted in the Proterozoic basement and some of them were connected with Early Palaeozoic synsedimentary movements and/or volcanism (Prague Fault, Tachlovice Fault, Tobolka Fault, etc.). Some transverse faults separate segments having structures incompatible to one another. This testifies to the transverse faulting simultaneous with the folding and to the basement fractures influencing the deformation of the basin filling. The distinct SE vergency of folds in the Silurian-Devonian of the synclinorium can be explained by the underthrusting of a basement block towards NW. Otherwise, the tectonic transport in the synclinorium was bilateral and the vertical component of displacements prevailed. The general tectonic character of the Prague Synclinorium testifies to its fully autochthonous relation to the Proterozoic basement. - Key words: structure, Ordovician, Silurian, Devonian, Variscan tectogenesis, Prague Basin, Barrandian, Czech Republic.
\end{abstract}

RÖHLICH, P. 2007. Structure of the Prague Basin: The deformation diversity and its causes (the Czech Republic). Bulletin of Geosciences 82(2), 175-182 (5 figures). Czech Geological Survey, Prague. ISSN 1214-1119. Manuscript received October 25, 2006; accepted in revised form December 11, 2006; issued June 30, 2007. DOI 10.3140/bull.geosci.2007.02.175

Pavel Röhlich, Pod Lysinami 23, 14700 Praha 4, Czech Republic

Tectonic deformation of the Ordovician to Devonian strata in the Prague Basin (Barrandian Region, Central Bohemia) shows a remarkable diversity. There are sectors of subhorizontal strata disturbed only by normal faults and flexures (W part of the Basin), whereas the E part of the Basin represents a real synclinorium (Prague Synclinorium) with various types of folds, from symmetrical to overturned ones. Longitudinal faults include both normal and reverse faults and thrusts. Transverse faults of various directions show both vertical and horizontal displacements - sometimes in combination - as well as more complex movements including rotation.

This diversity of tectonic deformation ways within a relatively small and clearly defined region presents a challenge for geologists aiming at comprehension of the deformation processes in their space and time relations.

\section{Regional diversity}

As mentioned above, there are differences between the gentle, germanotype deformation of the Ordovician filling the $\mathrm{W}$ part of the Basin and the more intensely disturbed $\mathrm{E}$ part with the Silurian and Devonian locally showing alpi- notype features (Havlíček \& Šnajdr 1955). Havlíček (1981) distinguished two segments of the Prague Basin (W and E ones) and explained this difference by the various mobility of the respective parts of the Barrandian Region. He assumed, however, a simple, flat structure of the Ordovician even under the Silurian and Devonian deposits. After Havlíček, the intense deformations of the Silurian and Devonian, including the longitudinal thrusts/reverse faults dipping to the basin centre, disappear in the clayey shales of the Bohdalec and Králův Dvůr formations (Upper Ordovician). This notion of longitudinal reverse faults disappearing in deeper levels of the synclinorium was introduced by Kodym (1924).

It must be stressed that the above concept may be valid only in the central part of the synclinorium. In the flanks built entirely of Ordovician, there are clear indications of faulting connected with the Proterozoic basement. For instance, reverse faults combined with folds, including overturned, are known in the Letná Formation in Prague (Vinohrady, Kunratice, Zbraslav, etc.). The question arises, which faults are rooted in the Proterozoic basement of the Prague Basin, and which of them are confined to the Palaeozoic basin filling only. In the $\mathrm{W}$ part of the Prague Basin, having a germanotype structure, the faulting evidently involves the basement. 


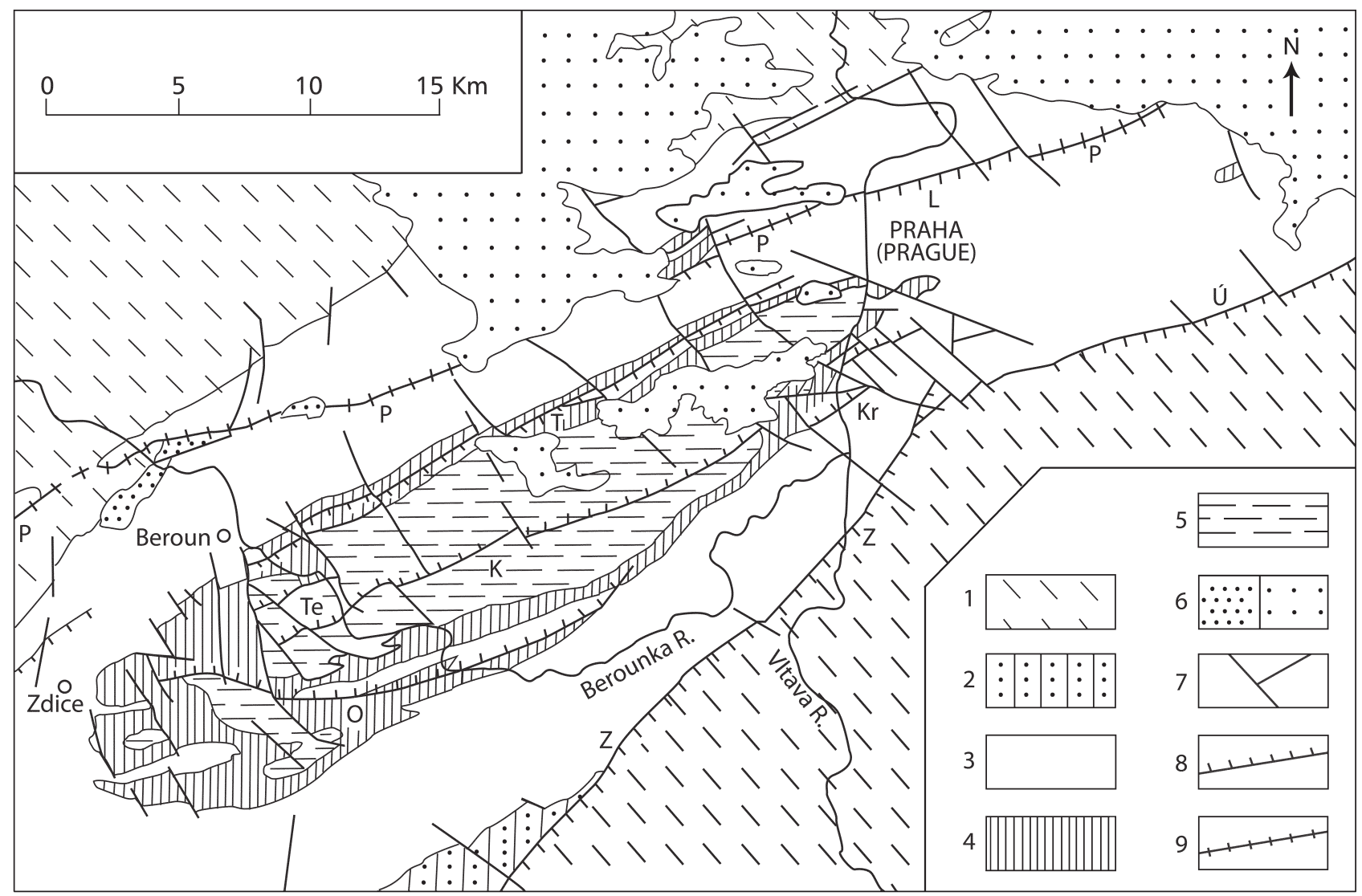

Figure 1. Sketch map of the Prague Synclinorium. 1 - Upper Proterozoic, 2 - Lower Cambrian, 3 - Ordovician, 4 - Silurian, 5 - Devonian, 6 - Carboniferous/Cretaceous, 7 - a fault in general, 8 - thrust/reverse fault, 9 - Prague Fault (P). Abbreviations: L - Libeň Thrust, T -Tachlovice Fault, Te - Tetín Thrust, K - Koda Thrust, O - Očkov Thrust, Kr - Krejčí’s Reverse Fault, Z - Závist Reverse Fault, Ú - Úvaly Thrust.

Therefore, only major faults in the E part (Prague Synclinorium) will be discussed briefly (Fig. 1).

\section{Longitudinal faults}

On the NW margin of the synclinorium, the unconformable contact between the Proterozoic basement and the Ordovician is clearly dissected by faults of various kinds. The longitudinal faults include thrusts and normal faults, both dipping NW (Fig. 2).

Farther from the basin margin, the prominent Prague Fault is located. It is the longest fault in the Prague Basin (ca $60 \mathrm{~km}$ ). The vertical displacement on the Fault amounts to $1800 \mathrm{~m}$ in Prague; the NW side is downthrown. The dip of the Prague Fault has been repeatedly discussed: NNW (normal fault) or SSE (reverse fault)? The Prague Fault is vertical on the only measurable outcrop (Hloubětín in Prague); it is apparently connected with a basement fracture. The question of the age and development of the Prague Fault (its kinematic history) appears to be a complex problem. Havlíček $(1963,1998)$ classified the Prague Fault as a normal fault; based on the facies development and palaeogeography, he drew conclusions about its Early Ordovician age and synsedimentary activity. He also considered the inversion of movements along the Prague Fault.

The detailed survey and geologic engineering works have revealed additional faults accompanying the Prague Fault in Prague (Fig. 3). It has been stated that the Prague Fault is dissected by younger longitudinal thrusts named Libeň Thrusts (Röhlich 1960, Havlíček 1963, Vorel 1982); the latter have gentle to medium dips (25-45, rarely up to 66 degrees) towards SSE. The dip of thrusts is often very close (generally parallel) to the dip of strata in the hanging wall. The sense of displacement is clear: thrusting from SE to NW. The displacement along one thrust may be estimated only at hundreds of metres. It can be assumed that thrusts of this group do not dissect the basement and peter out in the Ordovician SE of the Prague Fault. These younger thrusts probably released the stress from the synclinorium centre in the younger compressional phase (pre-Westfalian phase, after Havlíček 1963).

The Tachlovice Fault is the next fault frequently discussed in recent time. The Tachlovice Fault causes the duplication of some Upper Ordovician/Lower Silurian formations in outcrops. Between municipalities of Tachlovice 
and Beroun, the Tachlovice Fault approximately coincides with the boundary between two facies of the Wenlock: the prevailing graptolite shales in the NW and the volcaniccarbonate facies in the SE. Only scarce data are available about the dip of the Tachlovice Fault. About 50 degrees have been measured in the borehole Tachlovice (Prantl \& Přibyl 1945). After Horný (1965) the steepest dips (up to $80^{\circ}$ ) are in the E part; in the Loděnice area, the dips are very close to the dip of strata.

A short segment of the Tachlovice Fault is duplicated near Loděnice and a slice of Wenlock transitional facies is wedged in between the fault branches. Bouček (1941) was the first to describe the new road cut exposing the mentioned segment; he pointed out the striking facies differences within the exposed sequence and suggested the posibility of nappe structure. Horný (1965) came to the conclusion of a tectonic transport up to $1000 \mathrm{~m}$ on the Tachlovice Fault, having the NW direction (SE wall thrust over the NW one). Kř́žz (1991, 1998) was the next author to contribute to the Tachlovice Fault problem; he elaborated the concept of synsedimentary faults having influenced the Silurian facies development and volcanic activity. After this concept, the Tachlovice Fault (and/or a corresponding rupture in the basement) controlled the location and development of the Silurian volcanic centres of Svatý Jan pod Skalou, Reporyje and Nová Ves lining the Fault on the SE side. After Kř́̌̌ (1998), the Tachlovice Fault went through two movement inversions during the Silurian and resulted in a Variscan reverse fault.

The outlined concept is in a flat contradiction with the recently published hypothesis on the nappe structure of the Prague Synclinorium (Melichar \& Hladil 1999, Melichar 2004 , etc.). After the latter, the Tachlovice Fault represents the plane of a nappe transported from NW and subsequently deformed during forming the Prague Synclinorium (Synform). The main support pleaded for this concept is the incompatibility of the "deep-water facies of graptolite shales" with the adjoining shallow-marine sediments and volcanoclastics, locally even subaerial. The character of the Motol Formation representing the "graptolite facies" NNW of the Tachlovice Fault, however, admits of the origin in the protected shelf environment (calcareous shale, locally with bivalves, trilobites, etc.). The row of volcanoes aligned with the Tachlovice Fault could provide for a barrier protecting against the open sea influence. The smallscale deformations accompanying the Tachlovice Fault, allegedly testifying to the tectonic transport from NW to $\mathrm{SE}$, may represent submarine slumps reflecting the sea bottom dynamics. The latter is well documented with Lower Wenlock slump breccia exposed SE of Beroun-Lištice (Horný 1955, pl. IV).

Bare facts about the Tachlovice Fault are: the steep to medium dip towards SSE and relative displacement of the hanging wall towards NNW. The alignment of Silurian

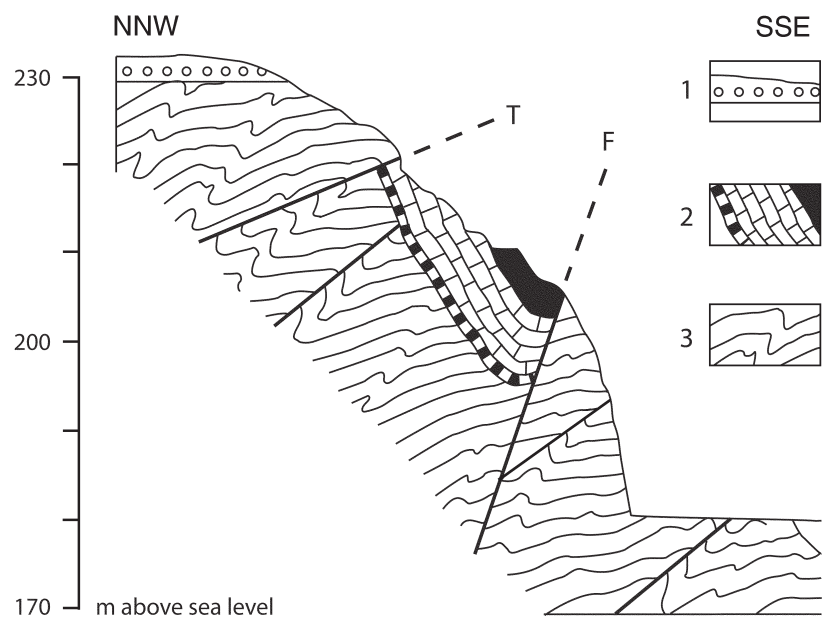

Figure 2. Example of longitudinal faults dissecting the ProterozoicPalaeozoic boundary in the Prague Synclinorium. Section exposed in the Prague Zoo (Troja). 1 - Pleistocene fluvial deposits, 2 - Ordovician basal conglomerate, tuff/tuffite, and iron ore (black), 3 - Upper Proterozoic. F - normal fault, T - thrust. After Fediuk \& Röhlich (1960).

volcanic centres with the Fault suggests a repeatedly active deep rupture in the basement. Some features of the Tachlovice Fault resemble the Prague Fault; similar complexities (e.g., younger faults analogous to the Libeň Thrusts) cannot be ruled out. The main Tachlovice Fault is locally associated with minor reverse faults and its identification is sometimes difficult.

A steep fault of disputable character (reverse or normal?) is exposed on the right bank of the Berounka River between Beroun and Tetín village, on the wooded slope close to the railway $\mathrm{km} 37.4$ (Kodym 1924). The fault plane strikes almost E-W and dips about $80^{\circ} \mathrm{S}$. The hanging wall is built of tuff agglomerate, the footwall of Wenlock biosperitic limestone. The fault is close (100-200 m) to the Tachlovice Fault and might belong to the rupture system feeding the Silurian volcanic complex.

Close to the axis of the Holyner-Hostim Syncline, the relatively short (about $3 \mathrm{~km}$ ) Tetín Thrust (overthrust) developed, extraordinary because of its partly subhorizontal to plunging position. The hanging wall has been clearly thrust to SSE. The Tetín Thrust was thoroughly described by Petránek (1951) thanks to excellent outcrops in the Tetín Gorge. The Tetín Thrust is important as an example of thrust confined to the Silurian-Devonian strata and apparently due to the release of stress in the centre of the main (Holyně-Hostim) syncline. The displacement on the Thrust could have amounted only about $200 \mathrm{~m}$ after the detailed cross section by Petránek (1951).

The most important longitudinal faults in the SE flank of the synclinorium are Koda and Očkov Thrusts, both inclined to the NNW. The Koda Thrust usually has two branches (the SE branch is the main one) and has been traced in the length of some $20 \mathrm{~km}$. It is a fold thrust associated with overturned 


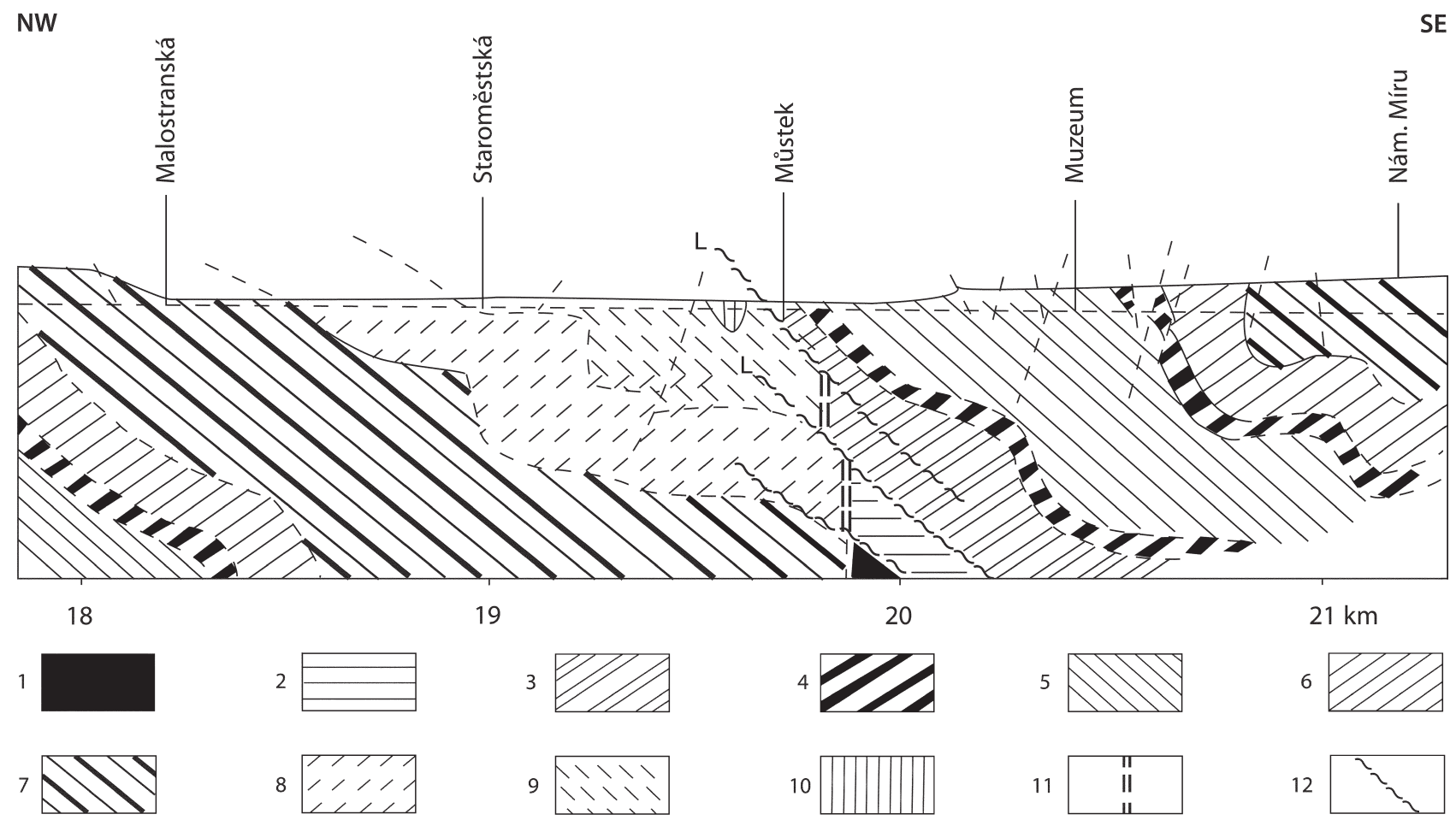

Figure 3. Cross section of the Prague downtown showing the Prague Fault and younger Libeň Thrusts. 1 - Upper Proterozoic, 2-10 - Ordovician: 2 Třenice and Mílina formations, 3 - Šárka Formation, 4 - Skalka and Řevnice quartzites, 5 - Dobrotivá Shale, 6 - Libeň Shale, 7 - Letná Formation, 8 Vinice Formation, 9 -Zahořany Formation, 10 - Bohdalec Formation, 11 - Prague Fault, 12 - Libeň Thrusts (L). Section drawn along the subway Line A, between Malostranská and Náměstí Míru stations. Vertical scale not exaggerated. Modified after Vorel (1982).

strata on both sides. The dip varies between 30 and $50^{\circ}$; the main (SE) branch is usually steeper. After Kř́̌ž (1998), the Koda Thrust corresponds to a fracture in the basement, being active during the basin development and influencing the sedimentation. After Melichar (2004), the Koda Thrust represents one overthrust branch connected with the Tachlovice Fault. The latter concept is in contradiction with the character of the Tachlovice Reverse Fault having an opposite sense of tectonic transport.

The Očkov Thrust is usually duplicated, too, and has been traced over $20 \mathrm{~km}$. In its W part, it is a typical thrust dipping $25-40^{\circ} \mathrm{N}$, whereas the E part dips steeper, $60-70^{\circ}$ : a transition from the thrust to the reverse fault (!). The Očkov Thrust was penetrated by the deep borehole T-1 (Tobolka) at the depth of $1200 \mathrm{~m}$. It is indicated by duplication of the Kosov and Králův Dvůr formations (Upper Ordovician). From the borehole log and the geologic map 1 : 25000 (Chlupáč et al. 1987, Chlupáč 1989), it results that Očkov Thrust is developed as a single fault in this section (Fig. 5). Interpolation between the borehole and the next outcrop of the Thrust corresponds to the dip of $35^{\circ}$.
The dips of strata on the outcrop suggest a possible decrease in the dip of the Očkov Thrust from ca $45^{\circ}$ (surface) to ca $25^{\circ}$ (borehole). The data also suggest an approximate parallelism between the fault plane and strata. The displacement between the hanging wall and footwall of the Očkov Thrust amounts to $2.5 \mathrm{~km}$ at least in the borehole site. This is the greatest overthrust documented in the Prague Synclinorium.

The so-called Krejčí's Reverse Fault (Kodym 1924) on the $\mathrm{S}$ margin of Prague has a position similar to the steeper E part of the Očkov Thrust. The duplication of the Ordovician-Silurian boundary formations in the form of Barrande's "Colonies" named Lahovská, Haidinger, Krejčí, Vinice and Hodkovičky, respectively, is due to this fault. After Kodym (1924) the Fault dips about $80^{\circ} \mathrm{NW}$ in the "Colony Krejčí" at Velká Chuchle.

The Závist Reverse Fault is the most prominent fault on the SE margin of the Prague Basin. It has a steep SE dip and mostly separates the Prague Basin from the adjoining Proterozoic. In the SE part of Prague, the Závist Reverse Fault gradually penetrates into the Ordovician while crossing its

Figure 4. Geologic sketch map of the area SE of Beroun. Adapted from the Basic geologic map of the Czech Republic $1: 25$ 000, sheet 12-413 Králův Dvůr and 12-411 Beroun. 1 - Upper Ordovician, 2 - Silurian, 3 - Lower Devonian to Eifelian, 4 - Devonian, Givetian, Srbsko Formation, 5 - fault (in general), 6 - reverse fault, 7 - thrust, 8 - line of the geologic cross section A-A' , B-B' (see Fig. 5). 
Pavel Röhlich • Structure of the Prague Basin: The deformation diversity and its causes

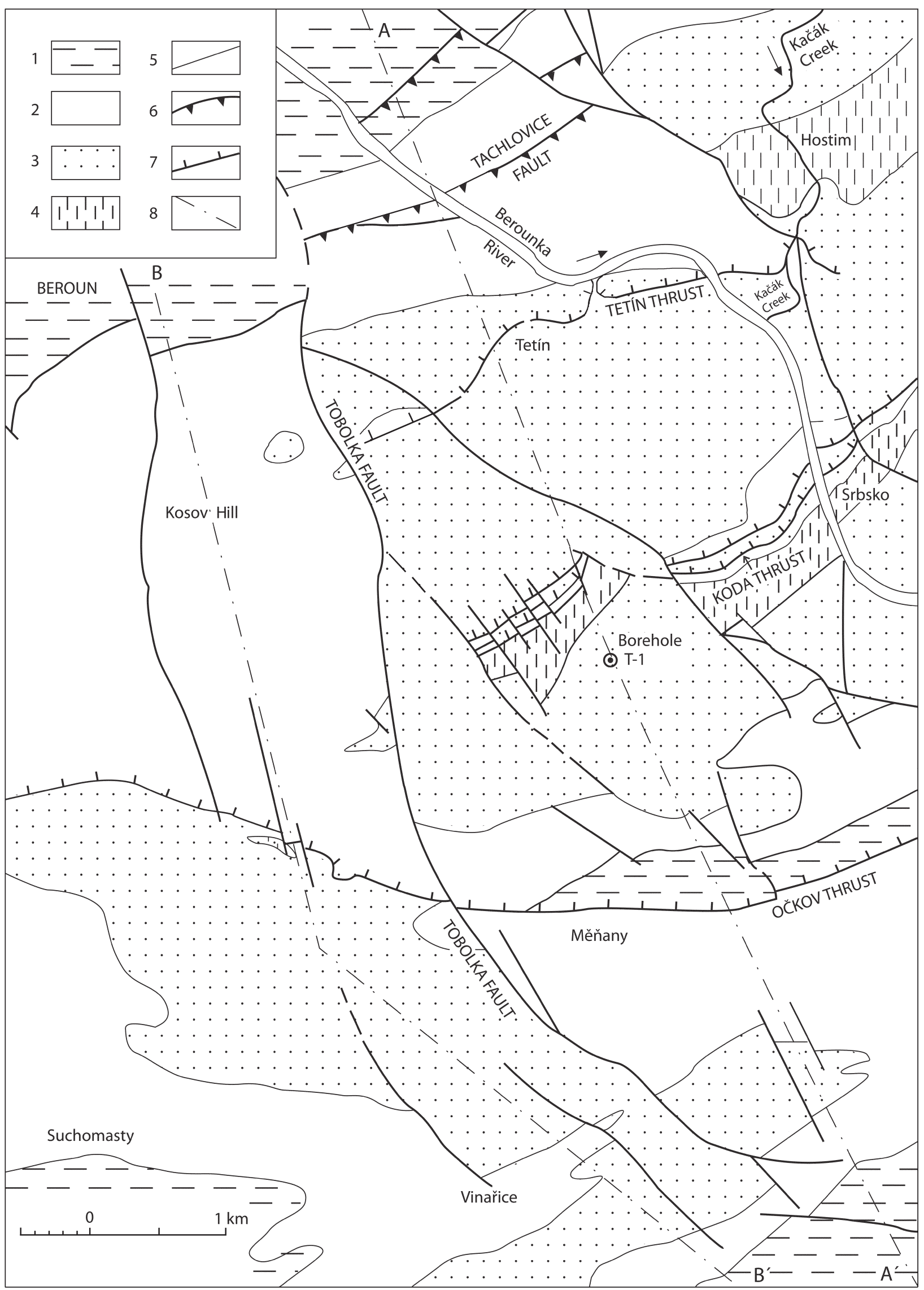


fold structure diagonally. This proves the activity of the Závist Reverse Fault in a later phase of the Variscan tectogenesis (pre-Westfalian phase after Havlíček 1963). The position of the Závist Reverse Fault on the boundary between two Proterozoic basement segments showing different development suggests a late manifestation of the so-called Klatovy Deep Fault activity (Röhlich \& Štovíčková 1968).

Additional reverse faults/thrusts, the so-called Úvaly Thrusts, have been stated at the Synclinorium SE margin E of Prague by Havlíček (1950). They have somewhat milder SE dips than the Závist Reverse Fault and are younger.

\section{Transverse Faults}

The transverse faults are very frequent in the Prague Basin, mainly in its E part. Kodym was the first to study them closely in the twenties of the 20th century. After Kodym (1921), the transverse faults were mainly products of the second phase of the Variscan folding when the stress was oriented parallel to the synclinorium axis. Consequently, Kodym considered most of the transverse faults as reverse faults. As early as in his study on the Prokopské Valley, however, Kodym (1918) observed that some transverse faults separated blocks with different fold structures: these faults must have been active during the folding. Therefore Kodym attributed the respective faults to the first phase of the Variscan folding.

Later survey by Svoboda \& Prantl (1949, etc.) and Havlíček (1963, etc.) brought many new data on the transverse faults but no systematic analyses of their age relationships. In the W part of the Prague Basin, having a complex mosaic-like fault pattern, however, this structure favoures the simultaneous activity of faults intersecting one another and the influence of basement faulting on the Variscan tectogenesis (Havlíček 1998).

Kříž (1998) included some transverse faults in the synsedimentary active faults in the Prague Basin. The Tobolka Fault (Fig. 4) is an example of repeatedly active fault par excellence. The extremely shallow-marine development of the Central Bohemian Devonian (reef in Pragian, hiatuses in Zlíchovian and Lower Givetian) is confined to the territory on the $\mathrm{W}$ of the Tobolka Fault. It is apparent that this transverse segment was set in a higher position from the Pragian to the end of the carbonate sedimentation in the Basin. On the other hand, the Silurian development testifies to a deeper position which was disturbed only by the activity of the Kosov volcanic centre adjoining the Tobolka Fault on its W side (Kř́ž 1998).

In addition to its synsedimentary activity, the Tobolka Fault was active simultaneously with the Variscan folding and thrusting. The Tobolka Fault intersects the Očkov Thrust and the resulting four blocks show different dis- placement and deformation ways (Fig. 4). The most remarkable change is the termination of some alpinotype tectonic elements in the NE block. Both branches of the Koda Thrust and the Tetín Thrust do not cross the Tobolka Fault. Displacements on the fault are opposite on the $\mathrm{N}$ and $\mathrm{S}$ sides of the Očkov Thrust. As a whole, the structures on the opposite sides of the Tobolka Fault are incompatible with each other (Fig. 5).

Transverse faults separating blocks with incompatible structures are relatively frequent in the Prague Synclinorium. Some of them are more or less arcuate: this may be due to the folding which continued along with the faulting and after that. The Tobolka Fault and some accompanying faults are very conspicuous in this respect. Transverse faults connected with structural incompatibilities are also frequent near the SW margin of Prague. NE terminations of the Tachlovice Fault and Koda Thrust are probably connected with certain transverse faults of this type.

The above transverse faults dividing blocks with incompatible structures are beyond the current classification of faults as they combine displacements of all types and directions (rotation, translation, strike-slip, vertical displacement). With regard to their special importance for the structure of the Prague Basin, I propose a working term "Kodym's Faults" to be used for them in the framework of the Barrandian Region (O. Kodym was the first to recognize their special character).

\section{Conclusions}

1. The majority of longitudinal faults in the Prague Basin (normal faults, reverse faults, and some thrusts) are apparently rooted in the Proterozoic basement. Several thrusts (Libeň Thrusts, Tetín Thrust) are confined to the basin deposits; they are probably due to the release of stresses within the Prague Synclinorium.

2. Some prominent faults rooted in the basement show indications of a long-term synsedimentary activity: Prague Fault, Tachlovice Fault, Tobolka Fault etc. (Havlíček 1998, Kř́íž 1998, etc.).

3. The SE vergences of folds in the Silurian-Devonian between Beroun and Prague as well as the prominent Očkov Thrust are probably due to underthrusting of a basement block towards NW. The Ordovician flanks of the Synclinorium show bilateral tectonic transport.

4. The evidence of an important part of transverse faults being active during the folding testifies to the role of transverse basement fractures in the Variscan tectogenesis. The Neoproterozoic basement, several times thicker than the basin deposits, must have been the main place of 


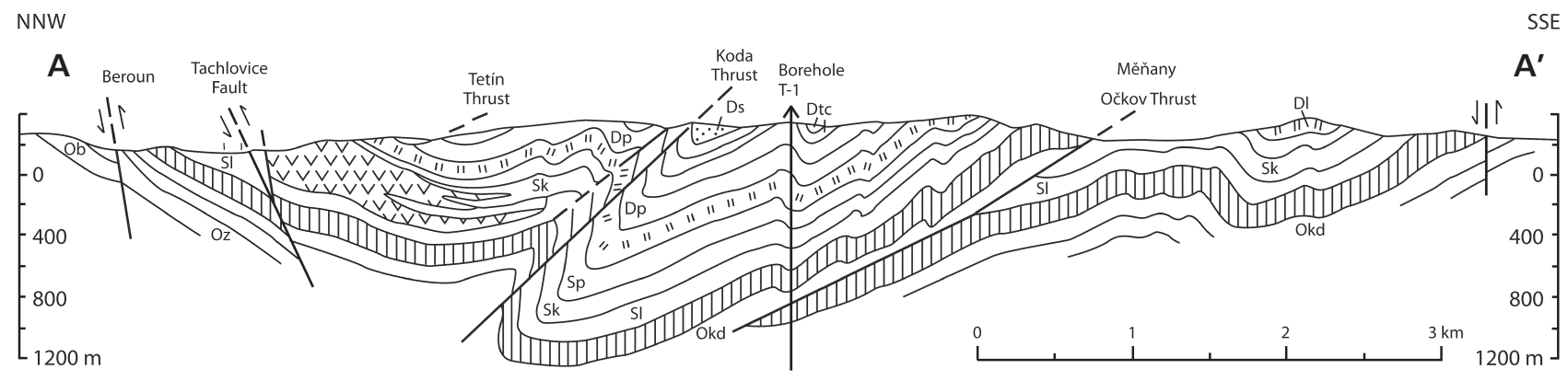

B

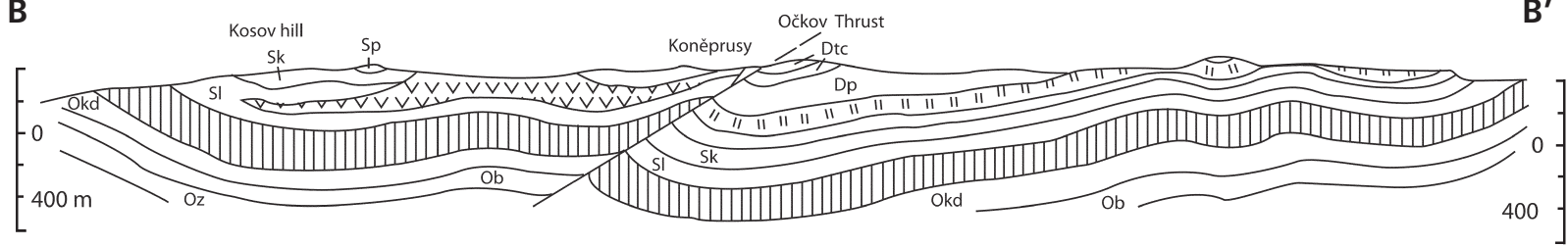

$B^{\prime}$

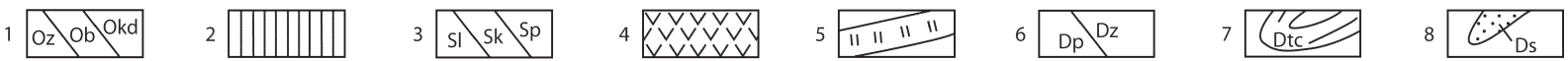

Figure 5. Cross sections of the central part of the Prague Synclinorium SE of Beroun (see Fig. 4). Section B-B' modified after Chlupáč (1989). 1 - Upper Ordovician: Zahořany, Bohdalec and Králův Dvůr formations, respectively, 2 - Uppermost Ordovician: Kosov Formation, 3 - Silurian: Liteň, Kopanina and Požáry formations, respectively, 4 - Silurian volcanic accumulations, 5 - Devonian: Lochkov Formation, 6 - Devonian: Praha and Zlíchov formations, respectively, 7 - Devonian: Třebotov and Choteč formations and their equivalents, 8 - Devonian: Srbsko Formation. Basalt sills omitted; vertical scale in metres below sea level.

work of the stress causing deformations. It is apparent that the stress mainly resulted in brittle failure of basement rocks, preferably along preexisting fractures. The basement faulting was projected into the overlying basin deposits. The $\mathrm{W}$ part of the Basin was affected only with block faulting and tilting whereas some underthrusting of the basement took place in the E part (Prague Synclinorium). This is documented with the displacement along the Očkov Thrust amounting to $2.5 \mathrm{~km}$ at least. The different mobility of transverse basement segments resulted in the development of the "Kodym's Faults", making the different deformations of the adjoining blocks possible.

5. The diversity of structures within the Prague Basin, ranging from germanotype to alpinotype features, is due to the inhomogenous, intensely ruptured (segmented) Proterozoic basement and its diverse reactions to the tectogenetic forces.

6. The close connection between the basement rupturing and the structural development of the basin filling supports the autochthonous character of the whole Ordovician to the Devonian sequence in relation to the Proterozoic basement.

\section{Acknowledgements}

Thanks for a fruitful discussion in the field are due to P. Budil, J. Frýda and Š. Manda. Valuable suggestions improving the manu- script from A. Dudek, K. Žák and O. Fatka are gratefully acknowledged. Thanks are expressed to D. Röhlich and H. Neubertová for technical assistence in processing the figures.

\section{References}

BouČEK, B. 1941. O novém odkryvu siluru u Loděnic. Zprávy Geologického ústavu pro Čechy a Moravu 17, 165-172.

Chlupáč, I., Brunnerová, Z., HavlíčeK, V., Kovanda, J., KŘíž, J., ŠalanskÝ, K., ŠTYCH, J. \& ZelenkA, P. 1987. Vysvětlivky k Základní geologické mapě ČSSR $1: 25$ 000, 12-413 Králův Dvưr. Ústřední ústav geologický, Praha.

CHLuPÁČ, I. 1989. Ed. Základní geologická mapa ČSSR 1 : 25 000, 12-413 Králův Dvůr. Ústřední ústav geologický, Praha.

FediuK, F. \& RÖHLICH, P. 1960. Basální vrstvy ordoviku v Praze-Troji. Acta Universitatis Carolinae, Geologica 1, 75-93.

HAVLÍČEK, V. 1950. Geologie úvalského staršího paleozoika. Sborník Státního geologického ústavu 17, 141-184.

HAVLíčEK, V. 1963. Tektogenetické porušení barrandienského staršího paleozoika. Sborník geologických věd, Geologie 1, $77-102$.

HAVLíčEK, V. 1981. Development of a linear sedimentary depression exemplified by the Prague Basin (Ordovician-Middle Devonian; Barrandian area - central Bohemia). Sborník geologických věd, Geologie 35, 7-48.

HaVlíčEK, V. 1998. Prague Basin, Ordovician, 39-79. In Chlupáč, I., HavlíčEK, V., KŘiž, J., Kukal, Z. \& ŠTORCh, P. Palaeozoic of the Barrandian (Cambrian to Devonian). Czech Geological Survey, Prague.

HAVLÍČEK, V. \& ŠNAJDR, M. 1955. Některé problémy paleo- 
geografie středočeského ordoviku. Sborník Ústředního ústavu geologického, Oddíl geologický 22, 237-255.

HoRNÝ, R. 1955. Studie o vrstvách budňanských v západní části barrandienského siluru. Sborník Ústředního ústavu geologického, Oddíl geologický 21, 315-447.

HornÝ, R. 1965. Tektonická stavba a vývoj siluru mezi Berounem a Tachlovicemi. Časopis pro mineralogii a geologii 10(2), 147-156.

KodyM, O. 1918. Tektonická studie v údolí Prokopském a jeho okolí u Prahy. Rozpravy České akademie věd a umění, Tř́ida II 27(6), 1-19.

KoDyM, O. 1921. Druhá fáze vrásnění variského v Barrandienu. Sborník Státního geologického ústavu 1, 83-109.

KodyM, O. 1924. Směrné přesmyky v Barrandienu. Rozpravy České akademie věd a umění, Tř́da II 33(1), 1-30.

KŘíž, J. 1991. The Silurian of the Prague Basin (Bohemia) - tectonic, eustatic and volcanic control on facies and faunal development. Special Papers in Palaeontology 44, 179-203.

KŘíž, J. 1998. Silurian, 79-101. In CHLuPÁČ, I., HAVlíčEK, V., KŘíž, J., Kukal, Z. \& ŠTorch, P. Palaeozoic of the Barrandian (Cambrian to Devonian). Czech Geological Survey, Prague.
Melichar, R. 2004. Tectonics of the Prague Synform: a hundred years of scientific discussion. Krystalinikum 30, 167-187.

MelichaR, R. \& HLADIL, J. 1999. Resurrection of the Barrandian nappe structures, central Bohemia. Geolines 8, 48-50, 1 inset poster.

PeTRÁNEK, J. 1951. Tetínské nasunutí. Věstník Královské české společnosti nauk, Tř́da matematicko-př́rodovědecká 1950(7), $1-13$.

Prantl, F. \& PŘibYL, A. 1945. Příspěvek k poznání geologických poměrů u Tachlovic. Rozpravy České akademie věd a umění, Tř́da II 54(3), 1-12.

RÖHLICH, P. 1960. Ordovik severovýchodní části Prahy. Rozpravy Československé akademie věd, Řada matematicko-prírodních věd 70(11), 1-64.

RÖHLICH, P. \& ŠŤOVíčKOVÁ, N. 1968. Die Tiefenstörungs-Tektonik und deren Entwicklung im zentralen Teil der Böhmischen Masse. Geologie 17(6/7), 670-694.

Svoboda, J. \& PrantL, F. 1949. Stratigraficko-tektonická studie o devonské oblasti koněpruské. Sborník Státního geologického ústavu Československé republiky 16, 5-92.

VOREL, J. 1982. Pásmo pražského zlomu ve vnitřní Praze. Věstník Ústředního ústavu geologického 57, 219-225. 